Ewa Jolanta STROIK

Uniwersytet im. A. Mickiewicza w Poznaniu

\title{
TURYSTYKA WYJAZDOWA NIEMCÓW - RYS HISTORYCZNY OD LAT PIĘĆDZIESIĄTYCH XX WIEKU DO WSPÓŁCZESNOŚCI
}

\section{Wstęp}

Rozwój turystyki w Niemczech stanowi temat ciekawy dla badaczy turystyki, ale też istotny dla osób tworzących ofertę turystyczną. Niemcy są narodem o bogatych tradycjach w odbywaniu podróży turystycznych. Od lat 50. XX w. po dzień dzisiejszy odgrywają ważną rolę w turystyce światowej, a także wpływają na kształtowanie aktualnych trendów (por. STROIK 2014). Dlatego warto poznać genezę status quo ante, aby lepiej rozumieć dzisiejsze status quo turystyki Niemców.

Celem niniejszego opracowania jest rozpoznanie zmian, jakie zaszły w turystyce wyjazdowej Niemców od lat 50. XX w. do współczesności. W badaniu wykorzystano metodę analizy niemieckich danych statystycznych, gromadzonych przez Forschungsgemeinschaft Urlaub Reisen (FUR) w sposób ciągły od lat 70. XX w., a także metodę analizy danych wtórnych i literatury przedmiotu, w oparciu głównie o źródła niemieckie. Podjęcie tematu uzasadnia fakt, że w polskiej literaturze przedmiotu rzadziej spotyka się wnioski wyciągnięte bezpośrednio w oparciu o analizę oryginalnych źródeł i danych niemieckich. 
Do zadań szczegółowych pracy należy analiza dynamiki wyjazdów w ujęciu ilościowym oraz analiza trendów w ujęciu jakościowym. Termin "analiza”, wywodzący się od greckiego analysis, oznacza rozbiór i określa „proces myślowy polegający na rozłożeniu pewnej całości na jej części składowe i rozpatrywanie, każdej z nich osobno. Badania analityczne w naukach empirycznych mają na celu przede wszystkim wykrycie struktury i mechanizmu działania" (APANOWICZ 2002, s. 24). Na etapie końcowym została podjęta próba syntezy - wyłonienia głównych trendów, które zmieniały się w ujęciu chronologicznym. Termin "synteza" także wywodzący się z języka greckiego oznacza „zestawienie”, czyli „łączenie wyodrębnionych czynników, elementów, części, cech, relacji, danego procesu, struktury lub organizacji. Synteza dokonana za pomocą takich operacji myślowych, jak porównanie, abstrahowanie i uogólnianie zmierza do wykrywania w połączonej, nowej całości istotnych właściwości i zależności" (APANOWICZ 2002, s. 25).

Rozwój niemieckiej turystyki zagranicznej i krajowej w ujęciu historycznym przedstawiony został $\mathrm{w}$ dwóch odmiennych organizmach państwowych, a następnie - po roku 1990, w zjednoczonym państwie. Rys historyczny, uwzględniający wzajemne zależności i uwarunkowania rozwoju niemieckiej turystyki wyjazdowej ułatwia zrozumienie dzisiejszego obrazu turystyki Niemców, która jest efektem działania wieloletnich procesów. Obserwację zachodzących zmian umożliwia ciągłość badań ruchu turystycznego, które były prowadzone $\mathrm{z}$ zastosowaniem tej samej metodyki w dawnej Republice Federalnej Niemiec od lat 70. XX w. do roku 1990, a po zjednoczeniu Niemiec w całych Niemczech (LOHMANN 1998).

Z uwagi na uwarunkowania historyczne przyjęto następujące cezury czasowe: od lat 50. XX w. do 1990 r. i od roku 1990 do współczesności. Początek lat 50. XX w. to okres krótko po powstaniu dwóch organizmów państwowych. W maju 1949 r. z trzech stref okupacyjnych (francuskiej, brytyjskiej i amerykańskiej) została utworzona Republika Federalna Niemiec państwo respektujące prawa demokratyczne. W październiku 1949 r. z radzieckiej strefy okupacyjnej powstała Niemiecka Republika Demokratyczna pod rządami niemieckich komunistów i pozostająca pod wpływami Związku Socjalistycznych Republik Radzieckich (PRONOBIS 1991). Drugą cezurę wyznacza rok 1990, w którym 3 października dokonało się zjednoczenie Niemiec. Od tego momentu badania obejmują jeden organizm państwowy aż do współczesności. 


\section{Turystyka wyjazdowa mieszkańców Republiki Federalnej Niemiec w latach 1949-1990}

\subsection{Czynniki determinujące rozwój turystyki i kierunki podróży}

Na rozwój przemysłu turystycznego w Niemczech największy wpływ miał ustrój polityczny (przykład Wschodnich i Zachodnich Niemiec). On bowiem określał ogólne ramy w zakresie dostępności oferty turystycznej, jej zasięgu, wpływał pośrednio na zasobność obywateli czy decydował o rozwoju infrastruktury niezbędnej do rozwoju turystyki.

W przypadku dawnej Republiki Federalnej Niemiec do dynamicznego rozwoju przemysłu turystycznego RFN przyczyniło się wiele czynników. Do najistotniejszych z nich należy zaliczyć:

- dynamiczny rozwój gospodarki, tzw. Wirtschaftswunder (cud gospodarczy), który wpłynął na bogacenie się społeczeństwa;

- rozwój dróg komunikacyjnych i linii kolejowych, który spowodował, że większa powierzchnia obszarów stała się dostępna dla turystów;

- rozwój przemysłu motoryzacyjnego, przede wszystkim lotniczego, który przyczynił się do wzrostu liczby wyjazdów turystycznych;

- zmiany w prawie pracy, a zwłaszcza zwiększenie liczby dni urlopowych i wprowadzenie w RFN w latach 50. XX w. pięciodniowego tygodnia pracy, które wywołały zmiany społeczne i sprawiły, że odbywanie podróży urlopowych stało się nieodłącznym elementem życia większości obywateli.

Bezpośrednio po zakończeniu drugiej wojny światowej turyści niemieccy nie byli mile widziani $\mathrm{w}$ wielu państwach europejskich. Dlatego poza lubianymi i popularnymi destynacjami krajowymi, tj. Alpy Niemieckie, Morze Północne i Bałtyckie, Szwarcwald czy Harc, Niemcy jako cel wyjazdów zagranicznych obrali Włochy i Austrię. W roku 1958 Italię odwiedziło 3,5 mln turystów (KAUFMANN, HILT 2014). Turystyka do Włoch w krótkim czasie zyskała znamiona masowości i powszechnej dostępności. Nad Jezioro Garda, a także do austriackiego Tyrolu kursowały tzw. Sonderzüge (z niem. pociągi specjalne). Fascynacja państwem śródziemnomorskim, klimatem, kulturą czy architekturą przenikała życie codzienne. Obserwując reklamy pochodzące $z$ lat 50 . i 60 . XX w. - uderzają $w$ nich nie tylko motywy śródziemnomorskie, ale też motywy podróży do Włoch, wszechobecne na plakatach reklamowych i na opakowaniach produktów spożywczych, sprzętów kuchennych, samochodów, skuterów, bombonierek lub gier planszowych 
(www.wirtschaftswundermuseum.de). Świadczy to o ogromnej sugestywności tematyki związanej z aurą urlopową Włoch.

Kolejnym odkryciem dla Niemców były Baleary, a głównie malownicza Majorka, na której w latach 50. XX w. rzadko kto władał językiem niemieckim. W 1950 r. Majorkę odwiedziło 100 tys. turystów niemieckich, rok później było ich już 200 tys. W latach 60. XX w. na Majorkę podróżowało już ponad milion turystów niemieckich rocznie, natomiast pod koniec lat 90 . liczba ta wzrosła sześciokrotnie do ponad $6 \mathrm{mln}$ rocznie (SCHULTENS 2014). Prominenci wybierali wyspę na siedzibę swoich drugich domów (KAUFMANN, HILT 2014). Od lat 70. XX w. wzrosło zainteresowanie turystów niemieckich Półwyspem Iberyjskim. Odbywanie podróży do dalekich destynacji tj. Tajlandia czy Malediwy, było udziałem nielicznych i oznaką prestiżu.

\subsection{Potencjał gospodarczy i wzrost znaczenia komunikacji}

Na tle dynamicznie rozwijającej się gospodarki w Niemczech Zachodnich turystyka również miała możliwości rozwoju. Siłami napędowymi rozkwitu gospodarki RFN były niewątpliwie takie czynniki, jak podejmowanie nowych inwestycji, nadwyżki siły roboczej na rynku pracy (ludność repatriowana), wdrożenie planu Marshalla, a także zachowany duży potencjał przemysłowy (WALCZAK 1976). Od lat 60. XX w. napływali robotnicy zagraniczni (niem. Gastarbeiter) z dawnej Jugosławii, Włoch, Turcji i Hiszpanii. Ich liczba w roku 1968 przekroczyła milion, a w roku 1971 - dwa miliony. W połowie lat 70. XX w. RFN znalazła się na drugim miejscu (po Stanach Zjednoczonych) w świecie kapitalistycznym pod względem obrotów w handlu zagranicznym (WALCZAK 1976).

Szybki rozwój gospodarczy przyczynił się do wzrostu dochodów i zamożności społeczeństwa. Obywatele Niemiec przeznaczyli w 1960 r. ok. $36,3 \%$ dochodu na żywość i używki, w latach 90. XX w. zaledwie $20 \%$ dochodu (SOELCH 1995). W obliczu stabilności zatrudnienia i posiadania wolnych środków finansowych $\mathrm{z}$ większą swobodą udawano się $\mathrm{w}$ podróż. Podróżowanie stało się czymś naturalnym i osiągalnym. Przyczyniły się do tego niewątpliwie zmiany regulacji prawnych dotyczące urlopu. W $1950 \mathrm{r}$. pracownikom przysługiwało 12 dni urlopu w roku, w 1990 r. było to już 30 dni. Czas pracy zredukowano do mniej niż 40 godzin w tygodniu, natomiast pracodawcy wypłacali pracownikom dodatek urlopowy. Rozwijał się też rynek kwater prywatnych, domków i mieszkań wakacyjnych, ponieważ większość istniejących hoteli zajęły zaraz po zakończeniu II wojny światowej 
wojska trzech państw okupacyjnych - amerykańskie, brytyjskie i francuskie (BELLERS 2005). Od lat 60. XX w. w Zachodnich Niemczech rozwijał się także timesharing, w opozycji do kupowania drugich mieszkan, tzw. cold beds (nieruchomości wakacyjnych, które przez większą część roku są nieużywane), zyskujących wielu zwolenników (KOSIŃSKA, STROIK 2014).

W latach 50. XX w. głównym środkiem transportu była kolej. Nic więc dziwnego, że ruch turystyczny rozprzestrzeniał się głównie wzdłuż linii kolejowych. Dla urlopowiczów kursowały specjalne pociągi tzw. Sonderzüge, jak np. Ferienexpress dowożący turystów do Włoch od roku 1951. W 1954 r. aż 56\% mieszkańców RFN preferowało podróż koleją - dla porównania w roku 1995 było to tylko 11\% (BELLERS 2005). Sukcesywnie modyfikowano linie kolejowe, wprowadzając elektryfikację i trakcję motorową oraz poprzez likwidację jednopoziomowych skrzyżowań z drogami (WALCZAK 1976). „W 1971 r. kolejami RFN podróżowało $1067 \mathrm{mln}$ osób, co stanowiło 14,3\% przewozów osobowych wszystkimi środkami lokomocji na terenie kraju" (WALCZAK 1976, s. 348). Dużą popularnością cieszyły się również zorganizowane podróże omnibusami - odbywano nimi około $20 \%$ podróży w latach 1950-1960, natomiast w 1973 r. znacznie mniej - zaledwie 5\% (BELLERS 2005).

Podobnie prężnie rozwijała się turystyka samochodowa. Z jednej strony dzięki innowacyjności w branży motoryzacyjnej, $\mathrm{z}$ drugiej strony dzięki dobrze rozwiniętej i utrzymanej sieci dróg i autostrad. W latach 70. XX w. drogi były dobrze oznakowane i wyposażone w zaplecze techniczne (WALCZAK 1976). „W 1973 r. sieć dróg ruchu ponadlokalnego liczyła 166668 km oraz $5258 \mathrm{~km}$ autostrad" (WALCZAK 1976, s. 348). Przybywało też samochodów. W roku 1973 było 18,5 mln samochodów osobowych, z których 2 / 3 było własnością pracowników (głównie robotników, funkcjonariuszy, urzędników). Warto nadmienić, że typowymi podróżami pozaurlopowymi były też krótkie wyjazdy weekendowe, cieszące się dużą popularnością.

\subsection{Touroperatorzy i turystyka lotnicza}

Od lat 60. minionego stulecia turyści niemieccy podróżowali na masową skalę, a dynamiczny rozwój firm turystycznych przyczynił się do powstania przemysłu turystycznego. Wyjazd urlopowy stał się "oczywistością" (SPÖREL 1998). Podróżowanie ułatwiały nowe rozwiązania w lotnictwie stosowanie silników odrzutowych spowodowało nasilenie ruchu turystycznego, w szczególności do państw basenu Morza Śródziemnego. W 1960 r. w podróż urlopową wyjechało $13 \mathrm{mln}$ Niemców (z RFN). Rok później było 
ich już $16 \mathrm{mln}$ (JACOBSEN 2014). Mieszkańcy dużych miast częściej podejmowali podróże edukacyjne i kształcące za ocean (BELLERS 2005). W Zachodnich Niemczech powstali liczni touroperatorzy: 1947 r. - „DER” Deutsche RB $\mathrm{GmbH}, 1962$ r. - Kaufhaustourismus z Quelle Reisen, 1964 r. - NUR (Neckermann und Reisen), 1967/68 TUI (Touristic Union International) (SOELCH 1995). Firmy rekrutujące się $\mathrm{z}$ branż niezwiązanych $\mathrm{z}$ turystyką rozszerzały profil działalności. Banki, domy towarowe, a nawet wydawnictwa wkraczały na rynek turystyczny - tak mocno zaznaczał się popyt na wyjazdy urlopowe. Konkurencja na rynku była silna - sytuacja firm nie cechowała się stabilnością, często dochodziło do upadłości, powstały też nowe firmy.

Dynamicznie rozwijał się także rynek linii lotniczych. W 1955 r. uruchomione zostały linie lotnicze Condor założone przez Thomas Cook AG, posiadające wówczas trzy samoloty z napędem śmigłowym. Lufthansa w 1962 r. przewiozła 32000 pasażerów. W 1969 r. samoloty z napędem śmigłowym zastąpiono Jumbo Jetem, który umożliwił odbywanie dalekich lotów.

$\mathrm{Z}$ upływem czasu firmy, które z sukcesem zakorzeniły się na rynku turystycznym, zabiegały o świadczenie pełnego wachlarza usług. Niezależne przedsiębiorstwa turystyczne, sieci hoteli i linie lotnicze zaczęły podejmować współpracę, by zapewnić sobie zyski i przewagę konkurencyjną, a klientom kompleksową obsługę. Firmy dominujące na rynku przejęły inne, malała liczba niezależnych organizatorów turystycznych. Organizatorzy, tacy jak Tui AG, Thomas Cook czy REWE, napędzali falę fuzji.

Reasumując można powiedzieć, że turystyka w RFN rozwijała się w warunkach gospodarki rynkowej. W ujęciu ilościowym dynamicznie i kontynuacyjnie wzrastała liczba odbywanych wyjazdów. Powstawanie licznych firm turystycznych uwarunkowane było wzrastającym popytem na usługi turystyczne. $W$ ujęciu jakościowym podróżowanie stało się zjawiskiem masowym, natomiast touroperatorzy, działając w warunkach nasilonej konkurencji, zabiegali o klientów, rozszerzając wachlarz świadczonych usług.

\section{Turystyka wyjazdowa w Niemieckiej Republice Demokratycznej}

\subsection{Rola państwa w kształtowaniu turystyki}

W zupełnie odmiennych warunkach rozwijała się turystyka w NRD. Rozwój turystyki sterowany był odgórnie $\mathrm{z}$ ramienia państwa oraz był reglamentowany. Podróżowanie stało się więc dodatkowym narzędziem „upolitycz- 
nienia" obywateli. Termin ten odnosi się zasadniczo do dwóch aspektów. Urlop w NRD stał się przedmiotem politycznej działalności, przede wszystkim poprzez występowanie państwa jako organizatora podróży urlopowej (GöRLICH 2007). Należy podkreślić, że sposób organizacji wyjazdu nie pozostawiał swobody - wiele wyjazdów miało narzucony program. „Odpowiedzialni funkcjonariusze [...] rozumieli urlop jako integralną część socjalizmu. Praca, czas wolny i urlop były widziane jako jedność, która daje się zrealizować jedynie w socjalistycznym porządku społecznym..." (GÖRLICH 2007, s. 67). Z drugiej strony podróże urlopowe stały się narzędziem propagandy socjalistycznej. Przypisywano symbole i znaczenia, które miały określać sposób mówienia i myślenia o urlopie, a także polityczne działania w jego obszarze. Posunięto się nawet do zmiany retoryki. W sposób świadomy zrezygnowano z używania zachodnioniemieckiego terminu "podróż urlopowa" (niem. Urlaubsreise) i zastąpiono go terminem "wyjazd wypoczynkowy” (niem. Erholungsaufenthalt), który miał podkreślać brak konieczności „ucieczki od codzienności" (KRÜGER 2013). Grupom urlopowiczów towarzyszyli często funkcjonariusze państwowi. Oczywiście owa notoryczna „obecność państwa" oraz daleko idąca inwigilacja obywateli prowokowała wielokrotnie sytuacje konfliktowe, które niejednokrotnie kończyły się represjami (GÖRLICH 2007).

Połowa wyjazdów wypoczynkowych była organizowana przez Feriendienst des Freien Deutschen Gewerkschaftsbundes (FDGB - Wolne Niemieckie Związki Zawodowe), które odpowiadały za pośrednictwo w przydzielaniu i przeprowadzaniu najczęściej wyjazdów dwutygodniowych do domów wczasowych. W 1956 r. przydzielono około 600 tys. częściowo dofinansowanych przez Związki Zawodowe wyjazdów urlopowych, przy czym kontyngent ośrodków wypoczynkowych był sukcesywnie rozbudowywany. Ponieważ nie dostosowano podaży do popytu - liczba oferowanych wyjazdów urlopowych stale była niewystarczająca. Najciekawsze miejsca wypoczynku przyznawano szczególnie „zasłużonym” członkom FDGB (www. mdr.de).

Innymi potencjalnie możliwymi formami podróży były wczasy z Biurem Podróży NRD (Das Reisebüro der DDR), kempingi lub „podróże prywatne" (GÖRLICH 2007). Biuro Podróży NRD było jedynym biurem podróży z licznymi filiami w kraju. Pośredniczyło ono w sprzedaży biletów kolejowych i lotniczych, zawierało także umowy z biurami w innych krajach socjalistycznych. Umowy podpisywano zazwyczaj na rok, regulowały one kwestie dotyczące liczby wyjazdów, ich miejsca, terminu, noclegów i wyżywie- 
nia, liczby uczestników oraz imprez kulturalnych. Podróżowano najczęściej w grupach 40-osobowych pod opieką pilota, zazwyczaj samolotem, rzadziej koleją. Można było także skorzystać z urlopu „indywidualnego", w którym biuro zapewniało jedynie nocleg i wyżywienie. Przykładowo podróż indywidualna do ZSRR wiązała się z koniecznością podania dokładnego miejsca i czasu pobytu oraz z meldunkami na milicji. Gdy się tego obowiązku nie dopilnowało, zarządzano akcję poszukiwawczą (BEYER, www.uni-leipzig. de). Popularnością cieszyły się wyjazdy na pola kempingowe. Ponieważ nie było ich wiele i dysponowały ograniczoną przestrzenią - wynaleziono namiot rozkładany na dachu trabanta tzw. Dachzelt (fot. 1), będący prawdziwym hitem.

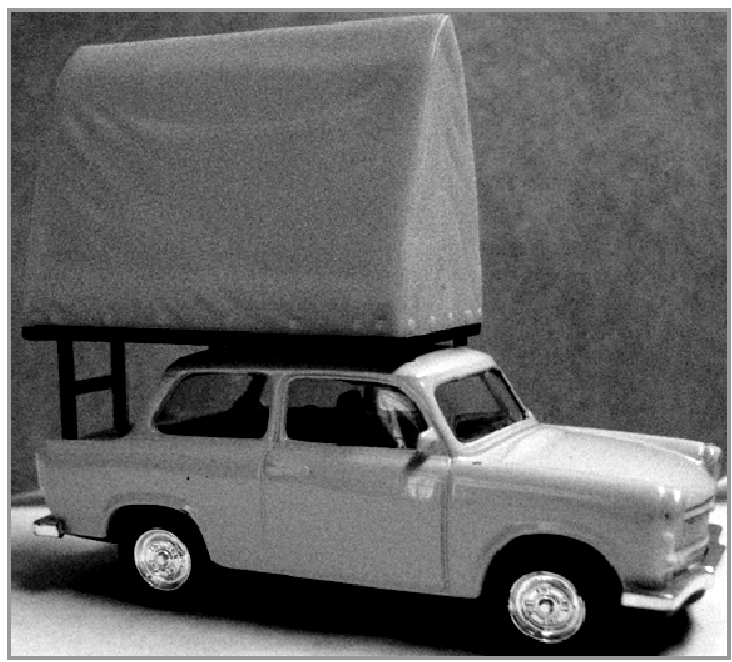

Fot. 1. Dachzelt

Źródło: http:/ / www.museum-digital.de

Mieszkańcy NRD podróżowali najczęściej nad Morze Bałtyckie, do Lasu Turyńskiego oraz do państw bloku socjalistycznego, a także na Kubę. Pobyty w krajowych ośrodkach wczasowych przedsiębiorstw wymieniano bezpłatnie $\mathrm{w}$ określonych terminach na pobyty $\mathrm{w}$ ośrodkach innych państw socjalistycznych - także na podstawie obustronnych umów (BEYER 2014). W przypadku wyjazdów zagranicznych obowiązywała dzienna stawka dewizowa była to maksymalna kwota waluty, jaką można było wymienić na dzień i zabrać ze sobą w podróż. Zabieranie większej ilości gotówki nie było dozwolone. 


\subsection{Indoktrynacja a literatura turystyczna}

Literatura podejmująca tematykę dotyczącą turystyki w NRD miała jako cel nadrzędny zapoznanie czytelnika $z$ osiągnięciami i pięknem ojczyzny socjalistycznej oraz innych państw bloku socjalistycznego (Wenzel 1955, za: GÖRLICH 2007). W literaturze turystycznej wyraźnie „podkreślone zostało rozgraniczenie od Zachodu i dokonał się od nowa podział dychotomiczny świata na przyjaciela i wroga, nowe i stare, dobre i złe. [...] Warszawa została porównana do Amsterdamu, Moskwa musiała mierzyć się z Rzymem i Paryżem. Tak negatywnie wypadał Zachód $\mathrm{w}$ tych porównaniach - $\mathrm{w}$ takim świetle pozostawał stale obecny w głowach obywateli NRD" (GÖRLICH 2007, s. 67).

Skrajnie odmienne niż w Zachodnich Niemczech uwarunkowania rozwoju turystyki sprawiły, że mimo podróżowania na masową skalę w Niemczech Wschodnich, nie mogły się tu rozwinąć prywatne przedsiębiorstwa turystyczne. Właściciele prywatnych kwater i pensjonatów nad morzem, wynajmujący aktywnie swoje lokale turystom, zostali w przeprowadzonej w 1953 r. akcji tzw. Aktion Rose aresztowani i wywłaszczeni, a ich majątki przejmowało FDGB (www.mdr.de). Natomiast wśród turystów pragnących odciąc się od narzucanych zewsząd ram słynne były tzw. zjawiska Freie Körper Kultur (FKK) - czyli plaże nudystów, które mimo licznych obostrzeń i zakazów - wpisywały się w pejzaż turystyczny NRD.

Turystyka w NRD, czyli za ,żelazną kurtyną" rozwijała się w sposób analogiczny do innych państw bloku socjalistycznego i była narzędziem politycznym państwa.

\section{Turystyka Niemców po zjednoczeniu kraju}

Poszczególne etapy historii Niemiec przed i po 1990 r. określane są często jako „vor der Wende” (przed przełomem, zjednoczeniem) i „nach der Wende" (czyli po zjednoczeniu). Zmianie uległa nie tylko sytuacja polityczna i ustrojowa Niemiec, ale przede wszystkim ekonomiczna. Po zjednoczeniu Niemiec obserwujemy procesy znacznego spowolnienia gospodarczego. Kraj znalazł się początkowo w trudnej sytuacji ekonomicznej, niwelowanie różnic między obu państwami okazało się kosztowne i długotrwałe.

Turystyka podlegała dalszym przeobrażeniom. Od lat 90. XX w. wyraźnie zarysowały się trendy: ceny lotów drastycznie spadły - dzięki tanim 
liniom lotniczym. Coraz większa liczba osób kupowała podróże przez Internet, krótko przed terminem wyjazdu i po porównaniu cen. Na skutek tego sukcesywnie malała liczba biur podróży. Niemcy nie odbywali jednej głównej podróży urlopowej $\mathrm{w}$ roku, trwającej trzy tygodnie, ale główny urlop uległ skróceniu na rzecz kilku wyjazdów krótszych. Wiosną popularne stały się krótkie wyjazdy do miast metropolii, z ang. citybreak, latem - urlop nad morzem, jesienią - weekend odnowy biologicznej, natomiast zimą - wyjazd na narty.

Niemcy są państwem o ujemnym bilansie turystycznym - dlatego z dużym zaangażowaniem podejmowane są działania na rzecz przyciągnięcia turystów do Niemiec. Przoduje w nich Niemiecka Centrala Turystyki (Deutsche Zentrale für Tourismus), zajmująca się na zlecenie rządu niemieckiego od ponad 60 lat promocją Niemiec jako destynacji turystycznej wartej odwiedzenia.

Oprócz danych statystycznych zbieranych przez Federalny Urząd Statystyczny (Bundesamt für Statistik), ruch turystyczny w Niemczech jest przedmiotem badań i analiz Instytutu Badawczego "Urlop i Podróże” (Forschungsgemeinschaft Urlaub Reisen - FUR). FUR przeprowadza corocznie badanie zachowań urlopowych pod nazwą Reiseanalyse (analiza podróży). Od $1971 \mathrm{r}$. badania te są prowadzone $\mathrm{z}$ zastosowaniem tych samych metod, a nawet pytań - co umożliwia porównanie wyników i uchwycenie wieloletnich procesów.

Analizując udział procentowy Niemców, którzy odbyli przynajmniej jedną podróż długookresową (5 i więcej dni) w ciągu roku widzimy, że w 1954 r. było to około 23\% obywateli RFN, w 1972 r. blisko 46\%, a w 1990 r. około $66 \%$. Po zjednoczeniu Niemiec w badaniach uwzględniono obywateli zjednoczonego państwa. Udział procentowy obywateli w wyjazdach długoterminowych rósł od zjednoczenia do 1995 r., w którym osiągnął prawie $80 \%$. Od tego momentu do współczesności utrzymywał się z niewielkimi wahaniami na stałym poziomie i wyniósł w roku 2013 - 77,9\% (www.fur.de).

Niemcy odbywają podróże z dużą regularnością, w większości przypadków corocznie. Liczba osób niepodejmujących podróży urlopowych maleje, wzrasta natomiast sukcesywnie liczba osób podejmujących wyjazdy każdego roku. W latach 2013-2014 stanowi ona ponad 60\% (rys. 1).

Wśród podejmowanych przez turystów niemieckich aktywności nadal cieszą się popularnością tzw. Pauschalreisen, czyli wyjazdy zorganizowane obejmujące pakiet usług, tj. przelot, transfer i pobyt w hotelu (tłumaczenie niemieckiego Pauschalreise jako imprezy turystycznej nie oddaje jej specyficz- 
nego charakteru). W 2013 r. tego typu wyjazdy zorganizowane stanowily $38 \%$ wszystkich podróży, natomiast aż $48 \%$ podróży zagranicznych (www. fur.de).

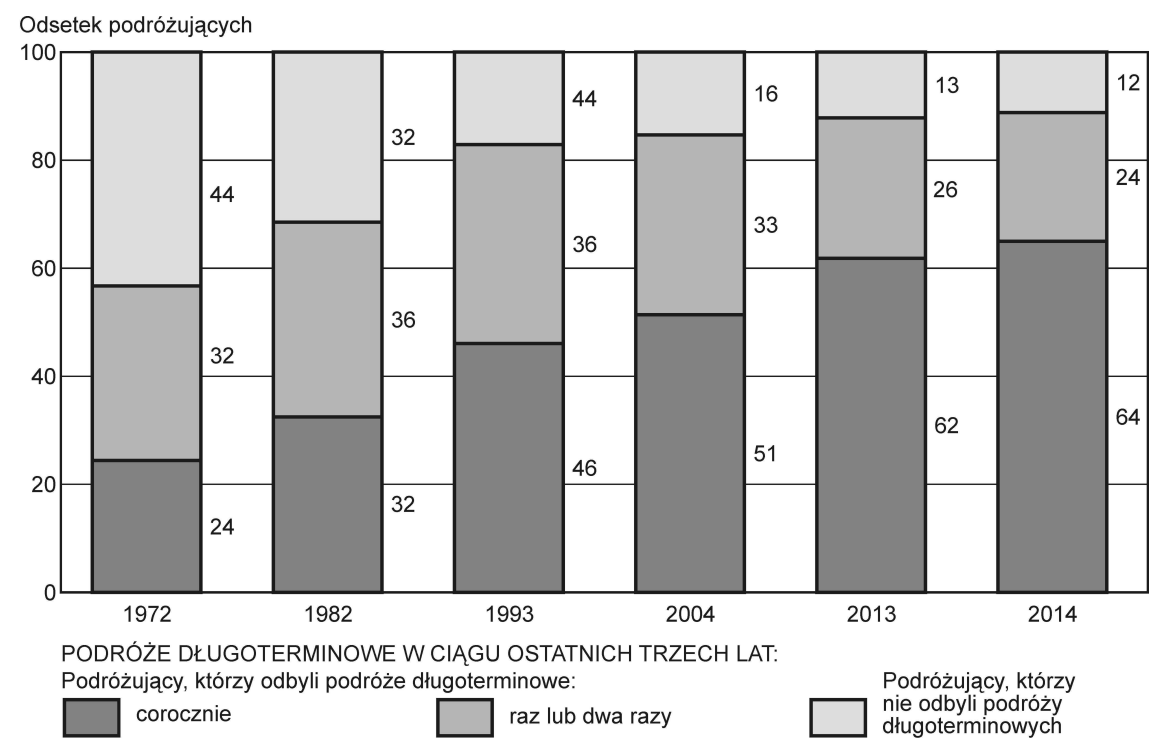

Rys. 1. Regularność w podróżowaniu Niemców w latach 1972-2014 (\%) Źródło: FUR (stan na styczeń)

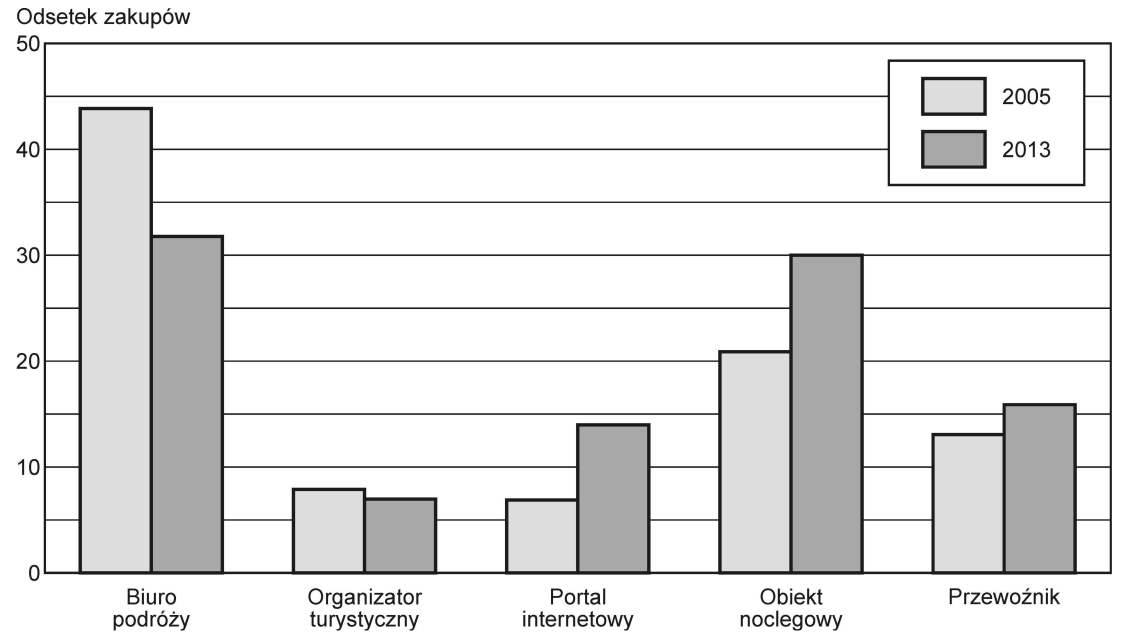

Rys. 2. Miejsce zakupu podróży urlopowej przez Niemców w latach 2005 i 2013 Źródło: FUR 2014 
Na przestrzeni ostatniego dziesięciolecia obserwujemy zmiany sposobu i miejsca zakupu podróży urlopowej (rys. 2). Coraz więcej wyjazdów kupionych zostaje przez Internet oraz bezpośrednio $\mathrm{w}$ obiekcie noclegowym. Maleje natomiast liczba podróży zakupionych w biurze podróży, co wpływa negatywnie na ich kondycję finansową, powodując $\mathrm{z}$ roku na rok zmniejszanie liczby biur podróży w Niemczech.

Dokąd zmierza współczesna turystyka w Niemczech? Coraz częściej $\mathrm{w}$ centrum uwagi pojawiają się zagadnienia związane $\mathrm{z}$ odpowiedzialnością społeczną, nie tylko w odniesieniu do turystyki. Badania FUR potwierdzają, że turyści niemieccy mają rozwiniętą świadomość ekologiczną. Na pytanie: „Na kim spoczywa odpowiedzialność społeczna za redukcję obciążeń ekologicznych spowodowanych przez podróże urlopowe?" respondenci w $2013 \mathrm{r}$. odpowiedzieli w następujący sposób: $65 \%$ jest zdania, że odpowiedzialność spoczywa na urlopowiczach, $57 \%$ twierdzi, że jest za to odpowiedzialny przemysł turystyczny, natomiast tylko $41 \%$ obarcza odpowiedzialnością państwo (www.fur.de). Podejmowanie tematu społecznej odpowiedzialności za zrównoważony rozwój turystyki zajmuje ważne miejsce $\mathrm{w}$ dyskusjach o roli, miejscu i negatywnych aspektach współczesnej turystyki.

\section{Wnioski}

1. Turystyka Niemców analizowana w okresie od lat 50. XX w. do współczesności ze względu na sytuację polityczną w dwóch różnych organizmach państwowych ma zupełnie inne uwarunkowania. W dawnej Republice Federalnej Niemiec rozwijała się swobodnie w warunkach gospodarki rynkowej, komercjalizacji. Podaż stanowiła reakcję na popyt, a turystyka szybko osiągnęła masową skalę. Inaczej stało się w przypadku Niemieckiej Republiki Demokratycznej, w której turystyka, mimo masowego charakteru, stała się narzędziem indoktrynacji i miała charakter monopolistyczny. Prywatne przedsiębiorstwa turystyczne nie mogły się rozwijać. Konsekwencje tak skrajnie różnych warunków rozwoju widoczne były po zjednoczeniu Niemiec i wpłynęły na dalszy rozwój turystyki.

2. W ujęciu ilościowym można powiedzieć, że w tym kraju istnieje rynek turystyczny kształtowany swobodnie $\mathrm{w}$ warunkach gospodarki rynkowej. Liczba wyjazdów turystycznych zwiększa się w ciągu roku, poprzez odbywanie kilku krótszych wyjazdów. Do zjednoczenia Niemiec turystyka w Za- 
chodnich Niemczech rozwijała się bardzo dynamicznie, po zjednoczeniu utrzymuje się nadal na wysokim poziomie, jednak wykazuje nieznaczny wzrost i okresy stagnacji.

3. W ujęciu jakościowym należy stwierdzić, że zmienia się sposób podróżowania poprzez łatwy dostęp przez Internet do oferty turystycznej i oferty tanich lotów czarterowych. Skróceniu uległ główny wyjazd urlopowy na rzecz kilku różnorodnych wyjazdów w ciągu roku. Obserwuje się nadal konsolidację rynku usług turystycznych w rękach największych touroperatorów. Sama oferta turystyczna dopasowana została do zmieniających się struktur demograficznych i społecznych społeczeństwa niemieckiego (starzenie się społeczeństwa, wzrost liczby jednoosobowych gospodarstw domowych).

4. Prowadzone w Niemczech badania monitorujące natężenie ruchu turystycznego z zachowaniem tych samych metod badawczych stanowią duży dorobek i umożliwiają obserwację trendów oraz prognozowanie ich dalszego rozwoju. Zauważalne jest to, że trendy w turystyce mają charakter ciągły podlegają jedynie okresowym wahaniom.

5. Ujemny bilans turystyki Niemców wpływa na wzmożenie akcji marketingowych. Troska o wspólne dobro i ochronę przyrody jest zauważalna w świadomości obywateli. Są oni przekonani, że aby przyciągnąć turystów, muszą dołożyć starań i podkreślić piękno własnej ojczyzny. Dlatego też od dziesięcioleci do współczesności popularne są działania pod hasłem: „Unser Ort soll schöner werden" (Nasza miejscowość powinna być piękniejsza).

6. Świadomość odpowiedzialności społecznej jest silnie rozwinięta i może być narzędziem do wdrażania działań na rzecz zrównoważonego rozwoju. Stosunkowo nową jakością są rozmaite akcje społeczne, uwrażliwiające na aktualne problemy humanitarne, gospodarcze i środowiskowe i znajdujące podatny grunt $\mathrm{w}$ społeczeństwie niemieckim, które wyraża swoje poparcie dla nich.

7. Obserwacja zmian zachodzących na niemieckim rynku turystycznym jest istotna, bowiem trendy te docierają do Polski i innych państw europejskich. Prognozowanie ich rozwoju ma wpływ na dostosowanie podaży i oferty do spodziewanego popytu.

8. Określenie i znajomość trendów dominujących w turystyce Niemców ma dla Polski ogromne znaczenie, ponieważ Niemcy stanowią główną i najważniejszą grupę turystów odwiedzających Polskę. Z tego względu szczegółowe rozpoznanie jest bardzo ważne dla dalszego kształtowania oferty przyjazdowej do Polski, by poprzez swoją atrakcyjność wychodziła ona naprzeciw oczekiwaniom i wymaganiom. 


\section{Bibliografia}

APANOWICZ J., 2002, Metodologia ogólna, Wyd. Bernardinum, Gdynia.

BELLERS J., 2005, Tourismuspolitik in Deutschland und in Siegen/Westfalen in den 50er und 60er Jahren Eine Quellenstudie, Scylda, Siegen.

BEYER R., Möglichkeiten für Urlaubsreisen der DDR-Bürger ins Ausland, www.uni-leipzig.de (12.09. 2014).

GÖRLICH Ch., 2007, Urlaub vom Staat. Zur Geschichte des Tourismus in der DDR, „Potsdamer Bulletin für Zeithistorische Studien", 38-39, s. 64-68.

HINTEREDER P. (red.), Tatsachen über Deutschland, http:// www.tatsachen-ueber-deutschland.de (13. 09.2014).

JACOBSEN N., Die Entwicklung der Touristikbranche, www.bmwi.de (11.09.2014).

Jahresbericht 2013, 2013, Deutsche Zentrale für Tourismus e.V.

KAUFMANN S., HiLT K., Geschichte des Reisens, http:/ / www.planet-wissen.de (14.09.2014).

KOSIŃSKA A., STROIK E., 2014, Timeshare - accessibility and legal regulations on Polish and German tourism market. Recognition of timeshare services on Polish tourism market. Tourism research in a changing world, [w:] F. Dias, E. Dziedzic, J. Kosmaczewska, A. Magliulo (red.), GITUR Tourism Research Group of Polytechnic Institute of Leiria, Portugal, s. 297-317.

KRÜGER S., 2013, DDR-Reisen, Als Nordkorea noch in der Südsee lag, www.welt.de (23.11.2014).

LOHMANN M., 1998, Die Reiseanalyse - Sozialwissenschaftliche (Markt-) Forschung zum Urlaubstourismus der Deutschen, [w:] Headrich G., Kaspar C., Klemm K., Kreilkamp E. (red.), Tourismus-Management, Tourismus-Marketing und Fremdenverkehrsplanung, Walter de Gruyter, s. 145-159.

PRONOBIS W., 1991, Polska $i$ świat XX w., Editions Spotkania, Warszawa.

Reiseanalyse 2014, Erste Ergebnisse, www. fur.de (11.09.2014).

SCHULTENS A., Tourismus auf Mallorca, www.planet-wissen.de (14.09.2014).

SOELCH A., Entwicklung des modernen Tourismus ab 18. Jh. in Europa, Universitaet Muenchen 1995, www.wirtschaftsgeografie.com (13.09.2014).

SPÖREL U., 1998, Die amtliche deutsche Tourismusstatistik, [w:] G. Headrich, C. Kaspar, K. Klemm, E. Kreilkamp (red.), Tourismus-Management, Tourismus - Marketing und Fremdenverkehrsplanung, Walter de Gruyter, s. 127-145.

STROIK E., 2014, Komercjalizacja ustug turystycznych na przykładzie rynku niemieckiego, [w:] S. Tanaś, J. Mokras-Grabowska, B. Włodarczyk, (red.), Od autentyczności do komercji - o doświadczaniu w turystyce, ser. „Warsztaty z Geografii Turyzmu”, 4, s. 121-135.

WALCZAK W., 1976, Republika Federalna Niemiec, PWN, Warszawa.

www.destatis.de (10.09.2014).

www.fur.de (11.09.2014).

http:/ / www.germany.travel/de (25.11.2014).

www.mdr.de (24.11.2014).

www.tui-group.com (15.09.2014).

www.wirtschaftswundermuseum.de (14.09.2014). 